\title{
THE EXISTENCE OF GROUPS OF METEORITE-PRODUCING FIREBALLS AND METEORITES IN COMET-LIKE ORBITS
}

\author{
N.A. Konovalova ${ }^{1}$, Yu.M. Gorbanev ${ }^{2}$, N.H. Davruqov ${ }^{3}$ \\ ${ }^{1}$ Institute of Astrophysics of the Academy of Sciences of the Republic of Tajikistan, \\ lnakonovalova@mail.ru \\ 2 Astronomical Observatory of Odessa National University, Ukraine, skydust@ukr.net \\ ${ }^{3}$ Institute of Astrophysics of the Academy of Sciences of the Republic of Tajikistan, \\ Naqqosh89@mail.ru
}

ABSTRACT. This paper discusses the existence of groups of meteorite-producing fireballs and ordinary chondrites in the Earth-crossing Jupiter-family comet-like (JFC) orbits. The similarity of the orbits of meteoriteproducing fireballs and those of meteorites in the groups was established by applying three criteria of orbital similarity - namely, the DSH criterion introduced by Southworth and Hawkins, the DDR criterion suggested by Drummond, and DN criterion reported by Jopek. We have detected six groups of meteorite-producing meteoroids and ordinary chondrites of L3.5-H5 types observed over the determined periods of increased fireball activity. Carrying out systematic and well-targeted observations, especially during the determined periods of increased fireball activity, enables to obtain reliable statistics from the collected observational data on the meteorite-producing meteoroids in order to determine their orbits, as well as their physical characteristics. The six target groups in this study, which contain 89 meteorite-producing meteoroids and six ordinary chondrites, may be groups of dynamically connected bodies. The genetic relationship between the investigated bodies within groups needs to be considered on the basis of the analysis of orbital evolution of the members of each group over the past several thousand years. The data on the mean heliocentric orbit of the group of meteorite-producing meteoroids enable us to link the group with its likely source, which may be either an asteroid, a family of asteroids or a comet, thereby making it possible to obtain information about the source itself. The search for potential parent bodies of the investigated groups of meteorite-producing fireballs and meteorites was carried out among new near-Earth asteroids. Consequently, several asteroids were selected in each group with the following criteria of the similarity between the asteroid orbit and mean orbit of the respective group: DD $\leq$ $0.06, \mathrm{DSH}$ and $\mathrm{DN} \leq 0.12$.

Keywords: group - fireball - meteorite - ordinary chondrite - orbit - comet - Jupiter family.

АБСТРАКТ. У статті розглянуто існування груп метеоритоутворюючих болідів і метеоритів із классу звичайних хондритів на кометоподібних орбітах типу JFCs, які перетинають земну орбіту. Близькість орбіт болідів і метеоритів в групах встановлювалася на основі трьох динамічних критеріїв близькості DSH- критерію Саутворт і Хокінса, DD-критерію Друммонда i DN-критерію Йопека. Виявлено шість груп метеоритоутворюючих метеороїдів та метеоритів 3 классу звичайних хондритів типу L3.5 - H5, що спостерігалися в знайдених періодах підвищення болідної активності.

Проведення систематичних і цілеспрямованих спостережень, особливо у зазначені інтервали часу підвищення болідної активності дозволяє отримати добре забезпечену статистику спостережних даних про метеоритоутворюючі метеороїди для визначення їх орбіт, а також їх фізичних характеристик. Досліджені групи, що включають 89 метеоритоутворюючих метеороїдів та 6 метеоритів 3 классу звичайних хондритів типу L3.5 - H5, можуть бути групами динамічно пов'язаних небесних тіл. Питання про генетичний зв'язок досліджених тіл в групі необхідно розглядати на основі аналізу еволюції орбіт членів групи на інтервалі в декілька тисяч років в минулому.

Дані про середню геліоцентричної орбіті групи метеоритоутворюючих болідів дозволяють зв'язати групу з ії ймовірним джерелом - астероїдом, астероїдним сімейством або кометою, і таким чином отримати інформацію про джерело. Серед астероїдів проведено пошук можливих батьківських тіл досліджених груп метеоритоутворюючих болідів і метеоритів. В результаті відібрано по кілька астероїдів для кожної групи 3 критеріями близькості орбіти астероїда i середньої орбіти групи: $\mathrm{DD} \leq 0.06, \mathrm{DSH}$ i $\mathrm{DN} \leq 0.12$.

Ключові слова: група - болід - метеорит - звичайний хондрит - орбіта - комета - сімейство Юпітера.

\section{Introduction}

The problem of asteroid and comet impact hazard (ACIH) has been becoming progressively more acute nowadays, especially considering the increasing number of nuclear power stations, chemical plants and hydroelectric power station dams, as well as the expansion of densely populated areas, and addressing this problem requires raising funds from different sources. To this end, national and international sky survey programmes employing various observation tools for the detection of potentially hazardous space objects have been developed to work out countermeasures against the threat these objects 
pose to our planet. Earlier, the Earth-crossing objects larger than $100 \mathrm{~m}$ were assumed to be potentially hazardous objects (PHO). However, this approach has been modified upon the Chelyabinsk meteor event took place on 15 February, 2013, in Russia [1]; hence now even objects smaller in decametric size $(>10 \div 20 \mathrm{~m})$ should be considered hazardous, especially due to their numerousness in the near-Earth space. The surveillance of fireballs using various observation tools enable to obtain more precise data on their atmospheric paths, orbits in the near-Earth space and coordinates of the predicted meteorite impact sites.

The importance of meteorite studies is also justified by the fact that chondrites, which comprise the most numerous group of meteorites, are similar in chemical composition to the Sun and represent the unprocessed primary matter from which the Solar System had emerged. The estimated daily mass influx of extra-terrestrial material to the Earth is within the range from 100 to 1,000 tons. Relatively large objects, i.e. meteorites, make up just about $1 \%$ of the above indicated total quantity. Three quarters of this quantity falls into the oceans while the majority of the remaining portion fall onto inaccessible or uninhabited and sparsely populated regions where meteorites are unlikely to be found. Most small meteorites, having fallen onto the ground, get lost among the terrestrial rocks. Obtaining data from fireball observations and finding meteorites, i.e. extra-terrestrial samples, are of great scientific importance with regard to understanding their origin and search for their sources in the Solar System.

2. Observations of meteorite-producing fireballs carried out by meteor stations and fireball networks

Observations of meteors and fireballs have been performed by meteor stations and fireball networks, which allow us to obtain data on the fireball passage through the atmosphere, its orbit in the near-Earth space, as well as coordinates of the meteorite impact site for sufficiently large bodies. With increasing statistics on the instrumentally observed meteorites, it has become possible to separate groups of meteorite-producing meteoroids from the sporadic meteoroid background in the near-Earth space.
The existence of meteoroid groups consisting of bodies producing meteorites was discussed in $[2,3]$ on the basis of well-determined fireball orbits obtained in the Canadian Meteorite Observation and Recovery Project (MORP) and by the U.S. Prairie Meteorite Network.

The current statistics on meteorite-producing sporadic bright fireballs and superbolides show that such events occur rather frequently - approximately once a week or fortnight [4]. Within the framework of the asteroid and comet impact hazard (ACIH) problem, it is crucial to carry out systematic observations of meteorite-producing fireballs, for which the data on the periods of activity are needed. To identify such periods of fireball activity, the distribution of quantity $\mathrm{N}$ of the observed sporadic bright fireballs and meteorites with known fall dates along the solar longitude L $\odot$ throughout the year was investigated using meteor observation data published in catalogues and academic journals [5]. As a result, we plotted a bar chart of annual distribution of quantity $\mathrm{N}$ of sporadic fireballs and superbolides with asteroid and comet-like orbits, as well as meteorites with known fall dates, including those with instrumentally determined atmospheric trajectory and orbits, in the solar longitude $\mathrm{L}_{\odot}$ with a time step of $2^{\circ}$. The resulting bar chart is shown in Fig. 1 wherein arrows indicate the dates of instrumentally recorded sporadic fireballs, after which the falls of known meteorites, i.e. chondrites of L3.5-H5 types with Jupiter-family cometlike orbits (namely Benešov, Neuschwanstein, Pribram, Park Forest, Košice and Mason Gully meteorites), took place. The obtained profile of annual activity of sporadic meteorite-producing fireballs and meteorites shows six major (1-6 Maj) and two minor (1-2 Min) periods of increased fireball activity throughout the year.

A potentially hazardous object in the Earth-crossing orbit can be detected while it is still in the near-Earth space and has not yet entered the Earth's atmosphere. There are already several on-going projects, e.g. the ATLAS project, developed for the early detection and monitoring of the short-period objects (with an orbital period of less than 20 years) approaching the Earth (with the perihelion distance $\mathrm{q}<1.3 \mathrm{AU}$ ), which can be either near-Earth Jupiter-family comets (NEJFCs) or near-Earth asteroids well before their

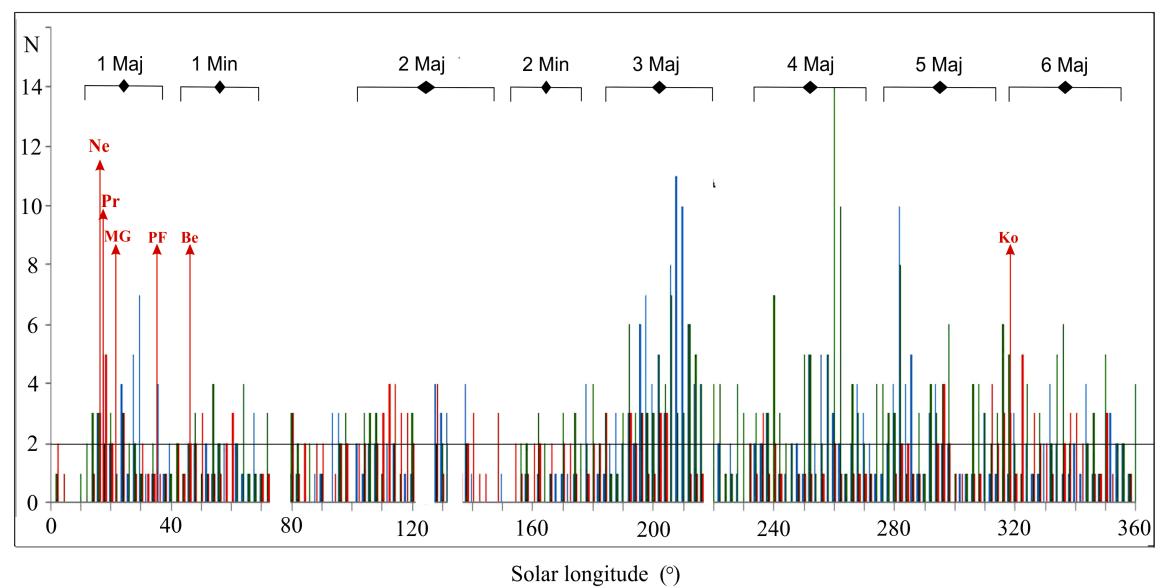

Figure 1: A bar chart representing the annual distribution of the quantity $\mathrm{N}$ of meteorite-producing sporadic fireballs and meteorites in the solar longitude $\mathrm{L}_{\odot}$. 


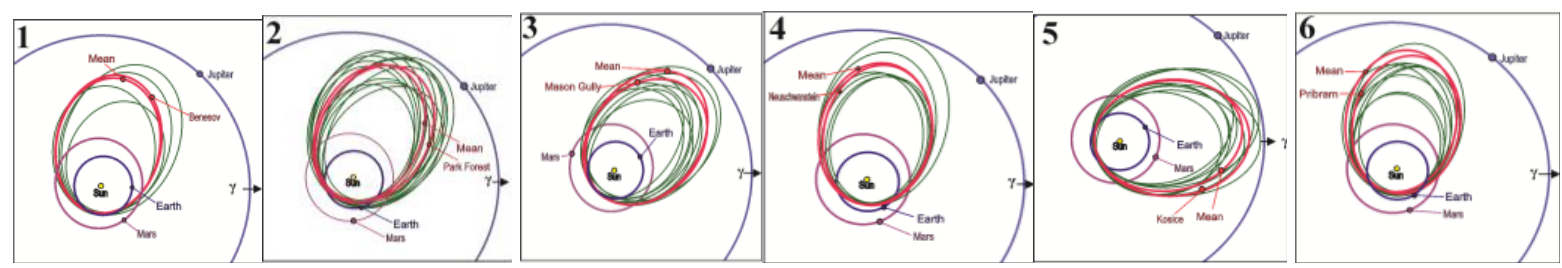

Figure 2: Meteorite and fireball orbits, as well as mean orbits of the six groups of meteorite-producing meteoroids, projected onto the ecliptic.

(NEAs). It is likely that in the nearest future it will be feasible to detect such objects as the Chelyabinsk meteorite entering the Earth's atmosphere, as well as to predict the likelihood of their fall onto the Earth's surface in the computationally predicted area. There have been two cases of the early detection of the objects approaching the Earth reported so far, whose fall was predicted well in advance, namely the Almahata Sitta meteorite (2008 TC3) [6] and the second object 2014 AA, which fell into the Atlantic ocean [7]. These cases have proved a clear need for systematic and well-targeted observations, especially during periods of increased fireball activity, in order to obtain reliable statistics on the meteoroids expected to produce meteorites which will enable to determine their orbits and physical characteristics. The collected observational statistic data will allow us to separate potential groups which may consist of potentially hazardous meteoroids based on the results of the analysis of orbital elements of the meteorite-producing meteoroids.

\section{The origin of groups of meteorite-producing me- teoroids and their sources}

There are observational evidences of the existence of rubble-pile asteroids, such as Itokawa and NEA 1950 DA [8]. Many of such asteroids could be formed from collisions between the Main-belt asteroids. According to their structure, rubble-pile asteroids are heterogeneous asteroids in the form of an aggregate of components held together by relatively weak gravity. Such asteroids can undergo tidal disruption during their close fly-bys around the planet within the Roche limit [9]. There are several other mechanisms that may cause the disintegration of an asteroid body, such as gravitational perturbations of Jupiter and other Solar System planets; the Yarkovsky - O'Keefe Radzievskii - Paddack (YORP) effect spin-up; thermal stress in the object may also result in its partial or complete break-up into a host of fragments of different size from decametric to metric sized ones and smaller. The resulting fragments form a group of asteroidal fragments, including meteorite-producing ones with identical heliocentric orbits, which being evolving gradually move to the Earth-crossing orbits due to the resonance effect primarily with Jupiter. Another possible mechanism of the formation of asteroidal fragments may be the collision between the asteroid and another space body, i.e. large meteoroid or small asteroid. Disintegration of asteroids, as well as of comets [10], results in the formation of groups of fragments, i.e. meteoroids of different size, in the near-Earth space in the orbits similar to those of their parent bodies.
4. Groups of meteorite-producing fireballs and ordinary chondrites in the Jupiter-family comet-like orbits

This study is aimed to investigate the possibility of the existence of groups of meteorite-producing meteoroids with Jupiter-family comet-like orbits in the near-Earth space, as well as the correlation between such groups of meteoroids and six known ordinary chondrites of L3.5-H5 type, which have been observed so far. The target groups of meteorite-producing meteoroids were named after the known meteorites comprising the respective groups. Scientific publications and meteor catalogues were used to search for meteorite-producing fireballs with orbits similar to the Jupiter-family comet-like (JFC) orbits of the six chondrites. The similarity of meteorite-producing meteoroid orbits with those of the six ordinary chondrites was established by applying commonly used criteria of orbital similarity (D-criteria), such as the DSH criterion introduced by Southworth and Hawkins [11], the DDR criterion suggested by Drummond [12] and DN criterion reported by Jopek et al. [13].

We determined whether the meteorite-producing fireball orbits are comet-like or not using the Tisserand parameter TJ calculated by formula (1):

$$
T_{j}=\frac{a_{j}}{a}+2 \cos i \times\left[\left(\frac{a}{a_{j}}\right)\left(1-e^{2}\right)\right]^{0.5},
$$

where a and aJ are the semi-major axes of a fireball and Jupiter, respectively; e and $i$ are the eccentricity and inclination of the fireball orbit to the ecliptic, respectively. For the comet-like orbits the value of the Tisserand parameter was $\mathrm{T}_{\mathrm{J}}<3.1$. Fig. 2 illustrates the orbits of meteorites and fireballs, as well as mean orbits of the six groups of meteorite-producing fireballs, projected onto the ecliptic.

The following data on the mean radiants and orbits of the groups, as well as meteorites comprising the respective groups, are given in Table 1: the right ascension $\alpha \mathrm{R}\left({ }^{\circ}\right)$ and declination $\delta \mathrm{R}\left({ }^{\circ}\right)$ of the radiant; out-of-atmosphere velocity $\mathrm{V} \infty(\mathrm{km} / \mathrm{sec})$; perihelion distance $\mathrm{q}(\mathrm{AU})$; semimajor axis a (AU); eccentricity e; orbital inclination $\mathrm{i}\left({ }^{\circ}\right)$; argument of periapsis $\omega\left(^{\circ}\right)$; and the longitude of the ascending node $\Omega\left(^{\circ}\right)$. The values of DSH, DDR and DN criteria of the similarity between the meteorite orbit and mean orbit of the group are presented in the last three columns of the table. 
Table 1: Groups of meteorites and meteorite-producing fireballs with similar orbits (J2000.0)

\begin{tabular}{|c|c|c|c|c|c|c|c|c|c|c|c|c|}
\hline Name & $\begin{array}{l}\alpha_{\mathrm{R}} \\
\left(^{\circ}\right)\end{array}$ & $\begin{array}{l}\delta_{\mathrm{R}} \\
\left.{ }^{\circ}{ }^{\circ}\right)\end{array}$ & $\begin{array}{l}\mathrm{V}_{\infty} \\
\mathrm{km} / \mathrm{s}\end{array}$ & $\begin{array}{c}\mathrm{q} \\
\text { a.e. }\end{array}$ & $\begin{array}{c}\text { a } \\
\text { a.e. }\end{array}$ & $\mathrm{e}$ & $\begin{array}{l}\mathrm{i} \\
\left(^{\circ}\right)\end{array}$ & $\begin{array}{c}\omega \\
\left({ }^{\circ}\right)\end{array}$ & $\begin{array}{l}\Omega \\
\left({ }^{\circ}\right)\end{array}$ & Ddr & Dsh & $D_{N}$ \\
\hline \multicolumn{13}{|c|}{ Group of meteorite Benesov } \\
\hline Mean & 224.0 & 40.6 & 19.3 & 0.948 & 2.360 & 0.588 & 20.4 & 211.6 & 53.4 & 0.00 & 0.00 & 0.00 \\
\hline Benesov & 227.6 & 39.9 & 21.1 & 0.925 & 2.483 & 0.627 & 23.7 & 218.4 & 47.0 & 0.04 & 0.08 & 0.08 \\
\hline (2000JF5) & & & & 0.911 & 2.065 & 0.559 & 13.8 & 216.8 & 58.1 & 0.060 & 0.162 & 0.160 \\
\hline$(2010 \mathrm{JH} 3)$ & & & & 1.054 & 2.706 & 0.611 & 21.0 & 228.0 & 42.8 & 0.070 & 0.141 & 0.139 \\
\hline \multicolumn{13}{|c|}{ Group of meteorite Neuschwanstein } \\
\hline Mean & 183.6 & -6.9 & 19.9 & 0.798 & 2.430 & 0.665 & 4.5 & 240.2 & 21.0 & 0.00 & 0.00 & 0.00 \\
\hline Neuschwa & 192.3 & 19.5 & 21.0 & 0.793 & 2.401 & 0.671 & 11.4 & 241.2 & 16.8 & 0.04 & 0.13 & 0.10 \\
\hline$(2005$ & & & & 0.749 & 2.105 & 0.644 & 2.70 & 219.6 & 48.9 & 0.051 & 0.108 & 0.106 \\
\hline$(2010 \mathrm{C}$ & & & & 0.850 & 2.226 & 0.618 & 5.41 & 233.1 & 34.3 & 0.054 & 0.103 & 0.103 \\
\hline \multicolumn{13}{|c|}{ Group of meteorite Park Forest } \\
\hline Mean & 173.6 & 10.8 & 19.3 & 0.830 & 2.486 & 0.663 & 5.1 & 233.6 & 6.5 & 0.00 & 0.00 & 0.00 \\
\hline Park Forest. & 171.8 & 11.2 & 19.5 & 0.811 & 2.530 & 0.680 & 3.2 & 237.5 & 6.1 & 0.03 & 0.09 & 0.09 \\
\hline & & & & 0.836 & 2.150 & 0.611 & 11.5 & 221.1 & 11.1 & 0.063 & 0.152 & 0.150 \\
\hline$(2013 \mathrm{E}$ & & & & 0.877 & 2.397 & 0.634 & 8.42 & 215.2 & 33.4 & 0.053 & 0.136 & 0.134 \\
\hline \multicolumn{13}{|c|}{ Group of meteorite Pribram } \\
\hline Mean & 184.4 & -4.5 & 19.8 & 0.795 & 2.495 & 0.664 & 3.8 & 238.3 & 25.9 & 0.00 & 0.00 & 0.00 \\
\hline Pribram & 192.3 & 17.5 & 20.9 & 0.790 & 2.401 & 0.671 & 10.5 & 241.8 & 17.8 & 0.06 & 0.13 & 0.13 \\
\hline (2013 GT79) & & & & 0.842 & 2.213 & 0.619 & 1.57 & 224.6 & 44.4 & 0.053 & 0.097 & 0.096 \\
\hline (2001OK153) & & & & 0.756 & 2.439 & 0.690 & 7.57 & 260.6 & 2.6 & 0.052 & 0.119 & 0.117 \\
\hline \multicolumn{13}{|c|}{ Group of meteorite Mason Gully } \\
\hline Mean & 151.9 & 10.9 & 16.8 & 0.905 & 2.455 & 0.624 & 5.3 & 41.1 & 176.8 & 0.00 & 0.00 & 0.00 \\
\hline Mason & 148.4 & 9.0 & 14.6 & 0.982 & 2.556 & 0.616 & 0.9 & 19.0 & 203.2 & 0.05 & 0.12 & 0.10 \\
\hline (2009 FS) & & & & 0.929 & 2.447 & 0.620 & 4.73 & 44.2 & 173.7 & 0.014 & 0.026 & 0.026 \\
\hline (2011 KK15) & & & & 0.948 & 2.436 & 0.611 & 1.25 & 342.8 & 230.7 & 0.042 & 0.105 & 0.101 \\
\hline \multicolumn{13}{|c|}{ Group of meteorite Kosice } \\
\hline Mean & 113.0 & 23.1 & 17.0 & 0.884 & 2.564 & 0.652 & 3.4 & 219.9 & 327.3 & 0.00 & 0.00 & 0.00 \\
\hline Kosice & 114.3 & 29.0 & 15.0 & 0.957 & 2.710 & 0.647 & 2.0 & 204.2 & 340.1 & 0.04 & 0.08 & 0.06 \\
\hline & & & & 0.848 & 2.504 & 0.662 & 2.52 & 64.7 & 122.5 & 0.040 & 0.108 & 0.106 \\
\hline (2011 KG13) & & & & 0.876 & 2.298 & 0.619 & 2.56 & 121.4 & 71.2 & 0.049 & 0.109 & 0.108 \\
\hline
\end{tabular}

\section{Physical characteristics of fireballs from the six me- teorite-producing meteoroid groups}

One of the important physical characteristics of a meteoroid is its structural strength that counteracts the disruptive effect of the aerodynamic pressure $\mathrm{P}_{\mathrm{dyn}}$ of the incoming atmospheric air flow during its plunging. The meteoroid disruption, which is usually accompanied by a bright flare, occurs when the aerodynamic pressure of the incoming air flow exceeds the meteoroid's threshold compressive strength. The aerodynamic break-up pressure $\mathrm{P}_{\text {dyn }}$, at which the meteoroid disintegration occurs, can be calculated by formula (2) [14]:

$$
P_{d y n}=\Gamma \cdot \rho a \cdot V 2,
$$

where $\rho \mathrm{a}$ is the atmospheric density at the height Hmax of the maximum brightness where the break-up occurred; V is the fireball velocity at the disruption point; $\Gamma$ is the drag factor $(\Gamma=1)$. Adopting graph (1) from the study [15], the meteoroid bulk density $\rho \mathrm{m}$ was calculated using the aerodynamic break-up pressure $P_{\mathrm{dyn}}$. The resulting bulk den- sity $\rho \mathrm{m}$ of the meteoroids of the six groups are given in Table 2.

The following causes may explain the observed differences between the bulk densities of fireballs calculated using the aerodynamic break-up pressure Pdyn and densities of meteorites $\delta \mathrm{m}$ resulted from the laboratory measurements:

1) When a fireball is plunging through the atmosphere, due to the atmospheric thermal effect (i.e. heating) the loss of volatile material occurs, which results in the fireball break-up into smaller, sturdier and denser fragments that are able to survive the fall through the Earth's atmosphere and land on the surface as meteorites.

2) The estimated fireball bulk densities $\rho m$ calculated using the aerodynamic break-up pressure Pdyn contain inaccuracies in the fireball height Hmax and velocity $\mathrm{V}$ measurements at the point of its breaking up into fragments, as well as in the applied value of the drag factor $\Gamma$. 
Table 2: Bulk densities of meteoroids of the six meteorite-producing groups

\begin{tabular}{|c|c|}
\hline Name of the group & Bulk density $\rho_{\mathrm{m}}\left(\mathrm{kg} / \mathrm{m}^{3}\right)$ \\
\hline Pribram meteorite group & $900 \div 1750$ \\
\hline Benešov meteorite group & $700 \div 1400$ \\
\hline Neuschwanstein meteorite group & $1150 \div 2050$ \\
\hline Park Forest meteorite group & $750 \div 1900$ \\
\hline Košice meteorite group & $1050 \div 1250$ \\
\hline Mason Gully meteorite group & $1050 \div 2000$ \\
\hline
\end{tabular}

\section{Results and conclusion}

We have detected six groups of meteorite-producing meteoroids and ordinary chondrites observed over the determined periods of increased fireball activity. The data on the mean heliocentric orbit of the group of meteoriteproducing meteoroids enables to link the group with its likely source, such as an asteroid, a family of asteroids or a comet, thereby making it possible to obtain information about the source itself. The obtained results in the context of the existence of groups of meteorite-producing meteoroids in the Jupiter-family comet-like Earth-crossing orbits indicate that large and strong fragments with comet-like orbits may overcome the disruptive effect of the Earth's atmosphere and reach the surface as meteorites. The six target groups, which contain 89 meteorite-producing meteoroids and six meteorites, may be groups of dynamically connected bodies. These groups may still comprise meteorite-producing meteoroids which can fall onto the Earth's surface as meteorites nowadays. It may serve as a good incentive for monitoring fireballs in these groups in the regions of their radiants over the determined periods of the fireballs activity. The investigation of the possibility of the existence of groups of meteorite-producing meteoroids and their sources is of practical value with regard to carrying out monitoring aimed at detection of potentially hazardous objects in the near-Earth orbits well before their entering the atmosphere.

In summary, we can conclude that meteorite-producing groups in the Earth-crossing comet-like orbits may contain large meteorite-producing meteoroids. The detailed study of physical and structural properties of this component of interplanetary bodies provides very important information about the sources of meteorites and meteorite-producing meteoroids from which they originated.

\section{References}

[1] Popova O.P., Jenniskens P., Emel'yanenko V., Kartashova A., et al.: 2013, Science, 342, Is. 6162, 1069.

[2] Halliday I., Blackwell A.T., Griffin A.A.: 1990, Meteoritics, 25, 93.

[3] Beech M.: 2006, WGN, the Journal of IMO, 34, 104.

[4] Spurny P., Borovicka: 2015, IAU General Assembly Meeting 29 - id.2253907.

[5] Konovalova N.A.: 2015, ДАН РТ, 58, No.7, 577.

[6] Jenniskens P., Shaddad M. H., Numan D., et al.: 2009, Nature, 458, 485.

[7] Farnocchia D., Chesley S.R., Brown P., Chodas P.W.: 2016, Icarus, 274, 327.

[8] Fujiwara A., et al.: 2006, Science, 312, 1330.

[9] Toth J., Veres P., Kornos L.: 2011, Mon Not. R. Astron. Soc., 312, 1527.

[10] Ibadinov Kh.I., Buriev A.M., Safarov A.G., Rahmonov A.A.: 2015, Adv. in Space Res., 56, 187.

[11] Southworth R.B., Hawkins G.S.: 1963, Smiths. Contrib. Astrophys., 7, 261.

[12] Drummond J.D.: 1981, Icarus, 45, 545.

[13] Jopek T.J., Farinella P., Froeschle Ch., Gonczi R.: 1995, $A \& A, \mathbf{3 0 2}, 290$.

[14] Bronsthen V.A.: 1981, Geophys. and Astrophys. Mon., Reidel, Dordrecht, $124 \mathrm{p}$.

[15] ReVelle D.O.: 2002, in Proc. of Asteroids, Comets, Meteors, Technical University Berlin, Germany (ESASP-500), 127. 